\title{
Performance of Reinforced Concrete Beam with Polystyrene Blocks at Various Regions
}

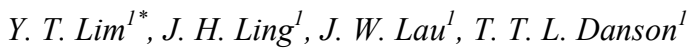 \\ ${ }^{1}$ School of Engineering and Technology, University t of Technology Sarawak, 96000 Sibu, Sarawak, Malaysia \\ *Email:yongtat93@gmail.com
}

\begin{abstract}
Lightweight materials, such as polystyrene, can be embedded in reinforced concrete (RC) beams to reduce its weight. However, this may, to some extent, affect the performance of the structure. This research investigates the behaviour of the lightweight beams under load and determines the best position of polystyrene blocks in beams. Nine specimens with a size of $175 \mathrm{~mm} \times 300 \mathrm{~mm} \times 1600 \mathrm{~mm}$ were tested under four-point load test. The number and position of polystyrene blocks in the beams were varied. The specimens were evaluated for effectiveness in terms of effective strength to weight ratio (s-w ratio). The lightweight beam was effective when the polystyrene blocks were placed at the neutral and tensile region, offering an s-w ratio of greater than 1 . The beam lost $3.8 \%$ strength with $8.4 \%$ reduction of weight.
\end{abstract}

Keywords: Reinforced concrete; lightweight system; replacement region; beam

Paper type: Research paper

\section{INTRODUCTION}

Reinforced concrete (RC) beam is widely used in the construction industry of Malaysia. It withstands the permanent and variable actions on a structure. Since the permanent action constitutes a significant portion of the design load, the cost of a structure could be reduced by using lightweight beams. This can be done by replacing some portions of concrete in the beams with lightweight materials like polystyrene [1], plastic balls [2] and Poly Vinyl Chloride pipe (PVC) [3].

Polystyrene is popularly used in beams as it is light, cheap, and easily handled. It can be positioned in the compression, neutral and tension regions of the beam [4]. However, an efficient lightweight beam design with a decent strength to volume ratio is yet to be found. For some reasons, the beams lose more strength than their weight, in percentage [5]. This leads to a question whether the system has been fully understood and optimized.

Theoretically, the flexural strength of an RC beam is governed by the tensile strength of the reinforcements and the compressive strength of the concrete. For low tensile resistance, the contribution of concrete in resisting bending is marginal. For that, the concrete in the tension region could be removed without significantly affecting the beam performance.

When lightweight materials were placed in the tension region, the reduction of strength was generally less than $7.0 \%$ [6]. For the compression and the neutral axis regions [3, 7], the reduction deviated significantly from $2.65 \%$ to $15.53 \%$. The position of the lightweight materials seemed to govern the beam performance, hypothetically. However, slight inconsistency is observed from the previous studies [7]. Thus, further study is required to gain a better understanding on lightweight beams.

This paper aims to investigate the performance of lightweight RC beams with polystyrene embedded in various regions of the beam. The beams were tested experimentally, and the responses were analysed in terms of the first crack load $\left(P_{i}\right)$, yield strength $\left(P_{y}\right)$, ultimate load $\left(P_{u}\right)$, stiffness $\left(\boldsymbol{E}_{o_{-}-\boldsymbol{E}_{\mathrm{u}}}\right)$, effective strength to weight ratio $(s-w$ ratio), deflection $(\delta)$, ductility $(\Delta)$ and the failure mode.

\section{METHOD}

Specimen details:

A solid beam (control specimen) and 8 lightweight beams were tested under the four-point load test (Fig. 1 and Table 1). The beams were $175 \mathrm{~mm}$ wide, $300 \mathrm{~mm}$ height and $1600 \mathrm{~mm}$ long. The effective length of the beam, $L_{s f f}$, between the supports was $1500 \mathrm{~mm}$.

Cylindrical polystyrene blocks (diameter, $d_{p}=50 \mathrm{~mm}$, length, $l_{p}=200 \mathrm{~mm}$, longitudinal spacing $=25 \mathrm{~mm}$ ) were longitudinally placed in the compression, neutral axis and tension regions of the beam (denoted as $\mathrm{C}, \mathrm{N}$ and $\mathrm{T}$ in Table 1). One to three units of blocks were embedded in the beam, as illustrated in Fig. 2. 
All specimens were reinforced with 2T12 and 2T10 high yield steel bars $\left(f_{y}=500 \mathrm{~N} / \mathrm{mm}^{2}\right)$ as the bottom and top reinforcements, respectively. The shear links provided was $11 \mathrm{R} 6-150$ mild steel bars $\left(f y=250 \mathrm{~N} / \mathrm{mm}^{2}\right)$. The concrete cover was $25 \mathrm{~mm}$.

The specimens were horizontally cast in plywood moulds. Ready-mixed concrete grade 25 was used. The maximum aggregate size was $20 \mathrm{~mm}$ and the designed slump was $60 \mathrm{~mm}$ to $180 \mathrm{~mm}$. The specimens were cured at the atmosphere temperature of $30 \pm 5^{\circ} \mathrm{C}$ and tested after 28 days of casting.
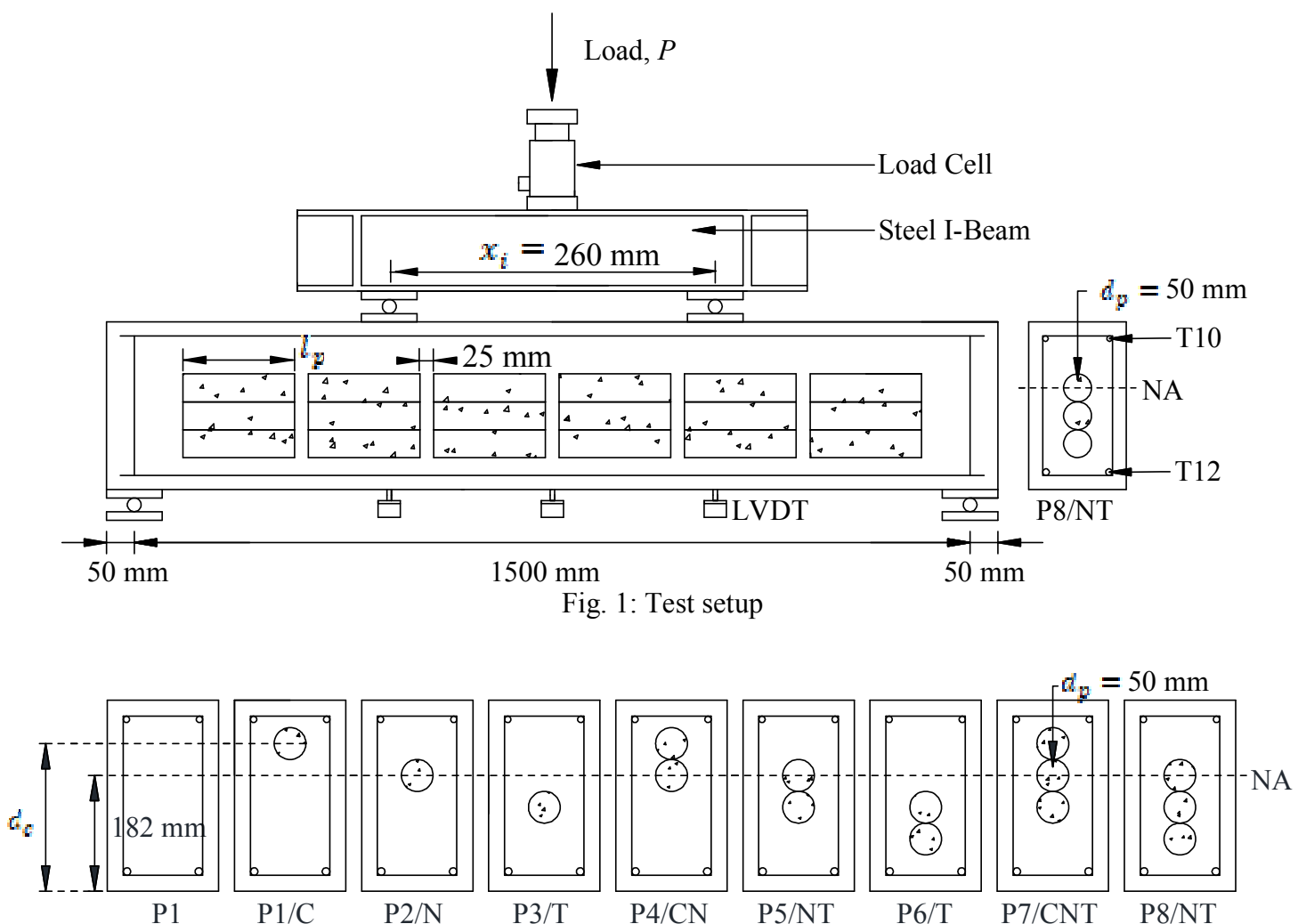

Fig. 2: Position of polystyrene by specimens

TABLE 1. SPECIMENS DETAILS

\begin{tabular}{cccc}
\hline Specimens & Region $^{{ }^{a}}$ & $\begin{array}{c}\text { Centroid of Polystyrene from } \\
\text { the Soffit, } d_{c(\mathrm{~mm})}\end{array}$ & $\begin{array}{c}\text { Percentage of } \\
\text { Replacement, } V_{(\%)}\end{array}$ \\
\hline $\mathrm{P} 1$ & - & - & - \\
$\mathrm{P} 1 / \mathrm{C}$ & $\mathrm{C}$ & 232 & 2.8 \\
$\mathrm{P} 2 / \mathrm{N}$ & $\mathrm{N}$ & 182 & 2.8 \\
$\mathrm{P} 3 / \mathrm{T}$ & $\mathrm{T}$ & 132 & 2.8 \\
$\mathrm{P} 4 / \mathrm{CN}$ & $\mathrm{C}, \mathrm{N}$ & 207 & 5.6 \\
$\mathrm{P} 5 / \mathrm{NT}$ & $\mathrm{N}, \mathrm{T}$ & 157 & 5.6 \\
$\mathrm{P} 6 / \mathrm{T}$ & $\mathrm{T}$ & 107 & 5.6 \\
$\mathrm{P} 7 / \mathrm{CNT}$ & $\mathrm{C}, \mathrm{N}, \mathrm{T}$ & 182 & 8.4 \\
P8/NT & $\mathrm{N}, \mathrm{T}$ & 132 & 8.4 \\
\hline
\end{tabular}

Note: ${ }^{\mathrm{a}} \mathrm{C}=$ Compression, $\mathrm{N}=$ Neutral, $\mathrm{T}=$ Tension

\section{Test Setup:}

The specimens were tested under the flexural load (Fig. 1). The distance between the applied loads, $x_{1}$, was $260 \mathrm{~mm}$, which was equivalent to $1 d$. A load cell was placed between the hydraulic cylinder and the distribution beam to measure the applied load. Three Linear Variable Differential Transducers (LVDT) were positioned under the specimen to monitor the deflection; at the mid-span and below the applied loads. All the measuring instruments were connected to a data logger for data acquisition. The specifications of the instrument used are outlined in Table 2. 
TABLE 2. INSTRUMENT SPECIFICATIONS

\begin{tabular}{ccccc}
\hline Instrument & Model & Description & Unit & Accuracy \\
\hline Hydraulic Jack & RR-10018 & Push $+933 \mathrm{kN}$, Pull -435 kN & - & - \\
\hline Hydraulic Pump & CEHCAP0001 & Control the hydraulic Jack & - & - \\
\hline Load Cell & CLJ-300KNB & Capacity 300 kN & $\mathrm{kN}$ & 0.01 \\
\hline LVDT & CDP-100 & Capacity 100 mm & $\mathrm{mm}$ & 0.01 \\
\hline Data Logger & TDS-530 & 30 Channels static data acquistion & - & - \\
\hline
\end{tabular}

\section{Test Procedure:}

Prior to the test, all the readings of the instruments were initialised to zero. The beam was preloaded to not greater than $10 \%$ of the predicted beam capacity for 5 minutes to consolidate the test setup. The applied load was then released for 5 minutes to observe the reading recovered to zero to check the validity of the measuring instruments. The process was repeated twice.

Next, the readings were re-initialised to zero and the test was started. An incremental load was applied at an interval of $5 \mathrm{kN}$ or $0.1 \mathrm{~mm}$ mid-span displacement, whichever achieved first. The load was maintained for at least 1 minute before the readings were recorded. The test stopped when the beam failed. The developments of cracks with respect to load were monitored and observed throughout the test.

\section{DISCUSSION}

\section{Material Properties:}

Tables 3 and 4 outlines the specifications of the materials used for the fabrication of beam. The properties were consistent, and the materials achieved the desired strengths.

TABLE 3. TEST RESULTS OF CONCRETE

\begin{tabular}{|c|c|c|c|c|c|c|}
\hline \multirow[t]{2}{*}{ Specimens } & \multicolumn{2}{|c|}{$\begin{array}{c}\text { Concrete Cube } \\
\left(\mathrm{N} / \mathrm{mm}^{2}\right)^{\mathrm{a}}\end{array}$} & \multirow{2}{*}{$\begin{array}{c}\text { Average } \\
\text { Compressive } \\
\text { Strength }\left(\mathrm{N} / \mathrm{mm}^{2}\right)\end{array}$} & \multicolumn{2}{|c|}{ Density $\left(\mathrm{km} / \mathrm{m}^{3}\right)^{\mathrm{a}}$} & \multirow{2}{*}{$\begin{array}{l}\text { Average } \\
\text { Density } \\
\left(\mathrm{km} / \mathrm{m}^{3}\right)\end{array}$} \\
\hline & S1 & $\mathrm{S} 2$ & & S1 & S2 & \\
\hline P1 & 25.0 & 25.5 & 25.3 & 2304.0 & 2325.3 & 2314.7 \\
\hline $\mathrm{P} 1 / \mathrm{C}$ & 25.5 & 25.2 & 25.4 & 2349.6 & 2353.8 & 2351.7 \\
\hline $\mathrm{P} 2 / \mathrm{N}$ & 25.5 & 25.2 & 25.4 & 2349.6 & 2353.8 & 2351.7 \\
\hline $\mathrm{P} 3 / \mathrm{T}$ & 26.1 & 26.8 & 26.5 & 2388.7 & 2372.7 & 2380.7 \\
\hline $\mathrm{P} 4 / \mathrm{CN}$ & 27.8 & 26.1 & 27.0 & 2372.7 & 2388.7 & 2380.7 \\
\hline $\mathrm{P} 5 / \mathrm{NT}$ & 27.0 & 25.7 & 26.4 & 2354.4 & 2333.6 & 2344.0 \\
\hline $\mathrm{P} 6 / \mathrm{T}$ & 25.8 & 25.2 & 25.5 & 2386.7 & 2384.6 & 2385.7 \\
\hline $\mathrm{P} 7 / \mathrm{CNT}$ & 25.8 & 25.2 & 25.5 & 2386.7 & 2384.6 & 2385.7 \\
\hline P8/NT & 25.0 & 25.5 & 25.3 & 2304.0 & 2325.3 & 2314.7 \\
\hline
\end{tabular}

Note: ${ }^{\text {a }}$ 1 = Sample 1, S2 = Sample 2

TABLE 4. TEST RESULTS OF REINFORCEMENT

\begin{tabular}{|c|c|c|c|c|c|}
\hline \multirow[t]{2}{*}{ Type of Steel Bar } & \multirow{2}{*}{$\begin{array}{c}\text { Diameter } \\
\left(\mathrm{mm}^{2}\right)\end{array}$} & \multicolumn{3}{|c|}{ Yield Stress $\left(\mathrm{N} / \mathrm{mm}^{2}\right)^{\mathrm{a}}$} & \multirow{2}{*}{$\begin{array}{l}\text { Average Yield Stress } \\
\qquad\left(\mathrm{N} / \mathrm{mm}^{2}\right)\end{array}$} \\
\hline & & $\mathrm{T} 1$ & $\mathrm{~T} 2$ & $\mathrm{~T} 3$ & \\
\hline \multirow[t]{2}{*}{ High yield steel bar } & 10 & 590 & 640 & 635 & 621.7 \\
\hline & 12 & 531 & 670 & 660 & 620.3 \\
\hline Mild steel bar & 6 & 290 & 279 & 285 & 284.7 \\
\hline
\end{tabular}

Note: ${ }^{\mathrm{a}} \mathrm{T} 1=$ Sample $1, \mathrm{~T} 2=$ Sample $2, \mathrm{~T} 3=$ Sample 3 


\section{Test Results of Specimen:}

The load-deflection response $(P-\delta$ curve) of the specimens are given in Fig. 3 and 4 . In general, the beam underwent (a) pre-cracking elastic stage, (b) post-cracking elastic stage, (c) yield point, (d) post-yielding stage, and (d) the ultimate stage. These responses were corresponded with the development of cracks on the beam. The typical crack pattern of the beam at the ultimate state is shown in Fig. 5.

Initially, prior to development of crack, the beam possessed a high degree of the stiffness. The first crack occurred at the mid-span around $30.45 \mathrm{kN}$ to $36.65 \mathrm{kN}$. The crack initiated from the beam's soffit and gradually propagated upward as the load increased.

Subsequently, the concrete in the tensile region forfeited from contributing the flexural strength. The tensile stress in the concrete transferred to the reinforcement bars in the beam. Under tension, the reinforcements elongated. The cracks developed when the deformability limit of the surrounding concrete was exceeded. As the load increased, the beam deflection enlarged, the cracks widened and propagated further, and the cracking regions expanded sideways toward the supports. Then, the ultimate load was identified when the applied load peaked.

The yield strength, $P_{y}$ and secant stiffness, $E_{0.75 u}$ of the specimen were determined using the method proposed by Noushini et al. [8] and Park [9]. From the $P-s$ curve (Fig. 3), two horizontal lines were constructed at the ultimate point, $P_{u}$, and $0.75 P_{u}$. The value of $0.75 P_{u}$ was used to determine secant stiffness, $E_{c_{v}} \boldsymbol{F}_{u}$ which was represented by the gradient of the straight line connecting the origin to the point $0.75 P_{u}$. The straight line was subsequently extended to intercept with line $P_{u}$. The yield point was below the interception on the $P$ - $\delta$ curve (Fig. 3 ).

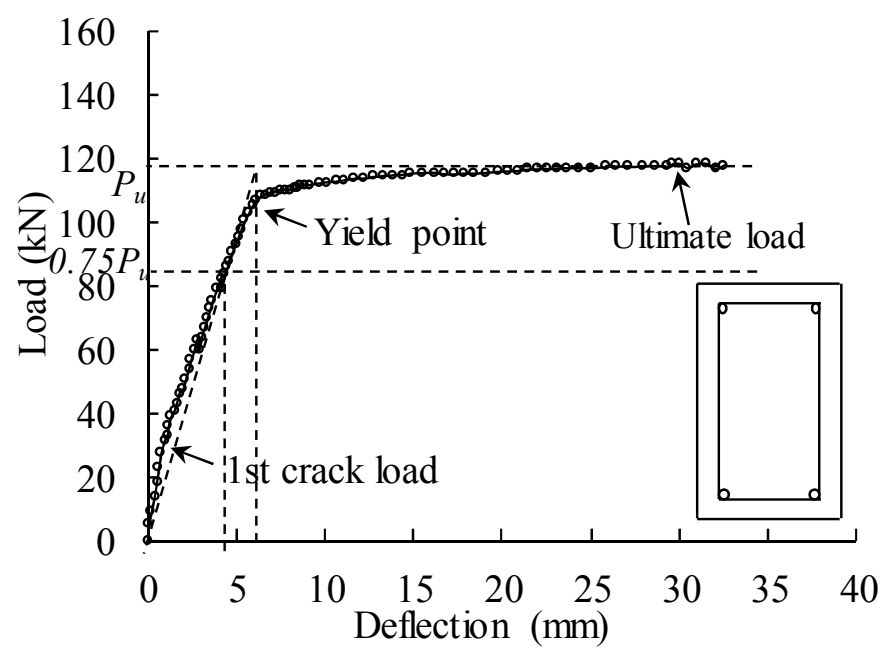

Fig. 3: Typical load-deflection response of solid beam (P1)

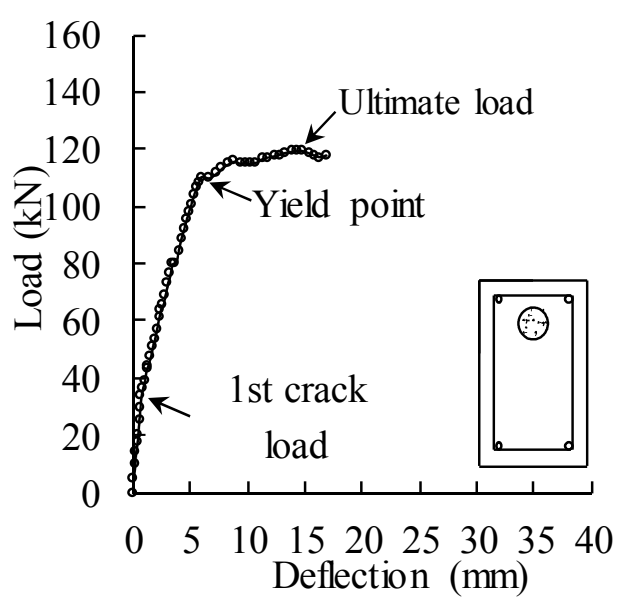

(a) Specimen $\mathrm{P} 1 / \mathrm{C}$

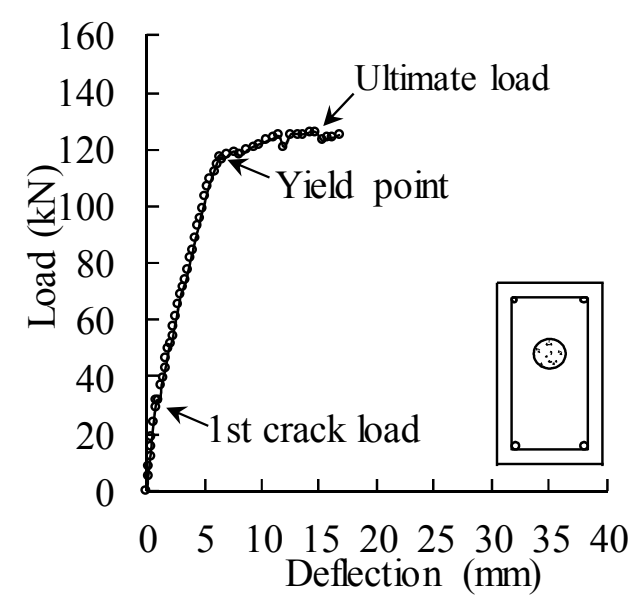

(b) Specimen $\mathrm{P} 2 / \mathrm{N}$

Fig. 4: Load-deflection response of lightweight beam 


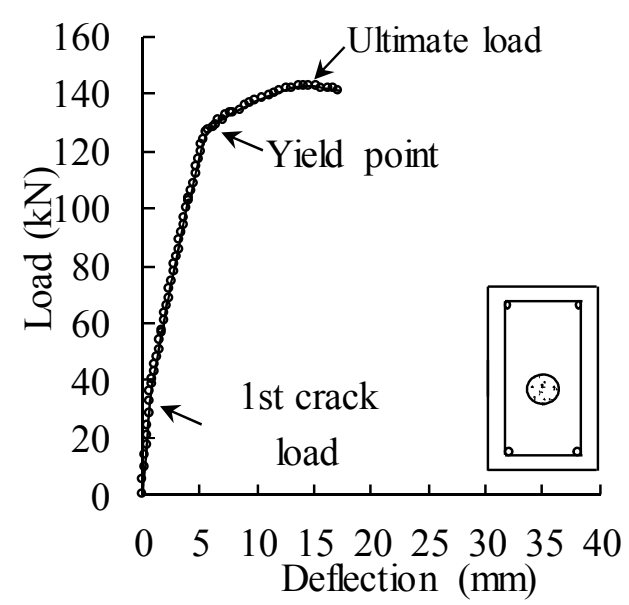

(c) Specimen P3/T

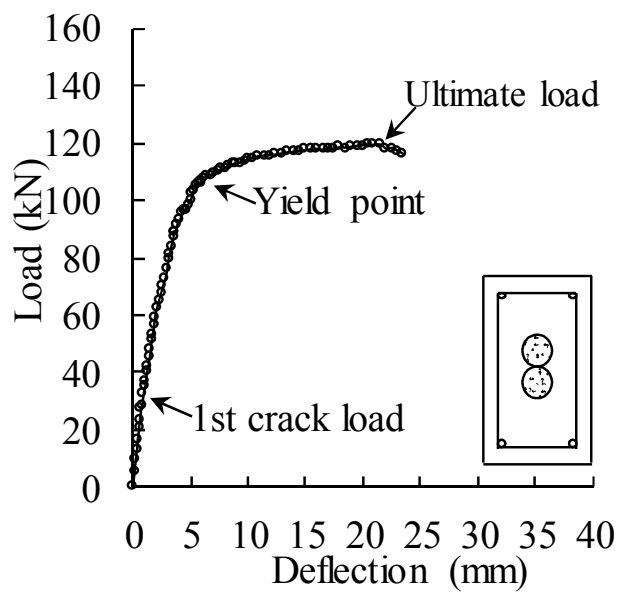

(e) Specimen P5/N

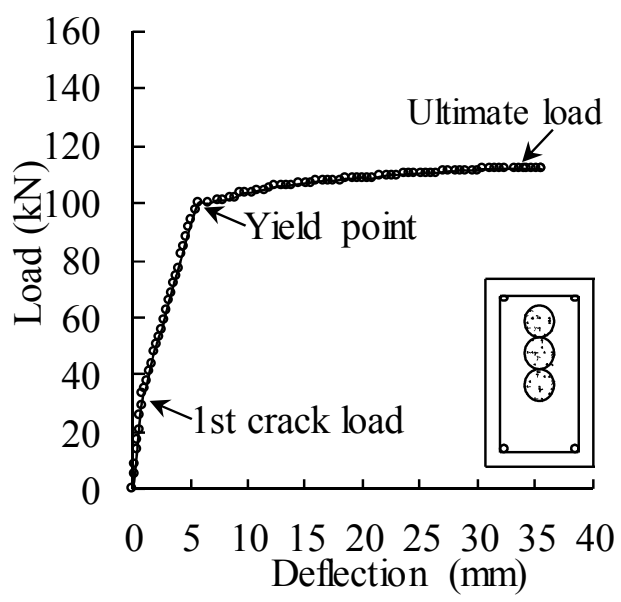

(g) Specimen $\mathrm{P} 7 / \mathrm{C}$

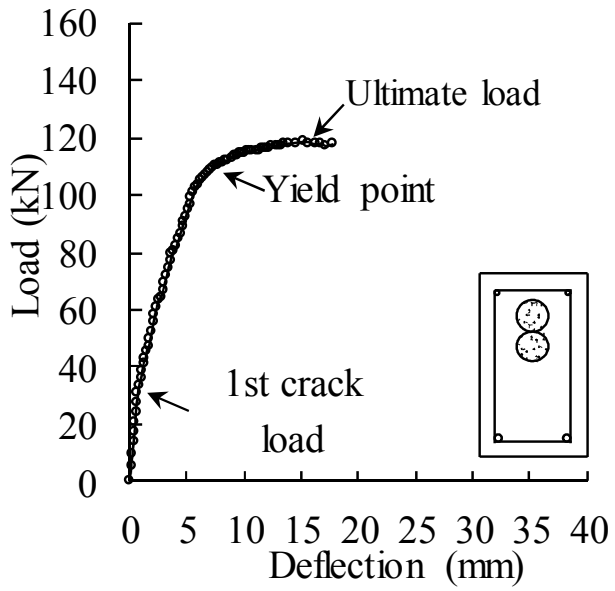

(d) Specimen $\mathrm{P} 4 / \mathrm{C}$

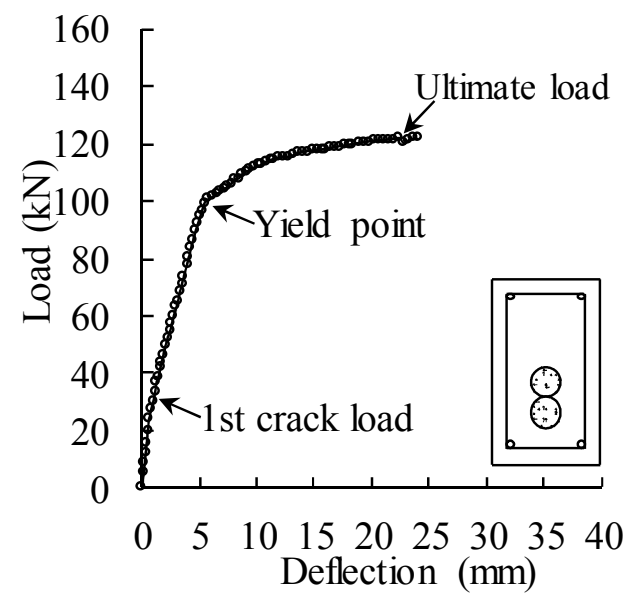

(f) Specimen P6/T

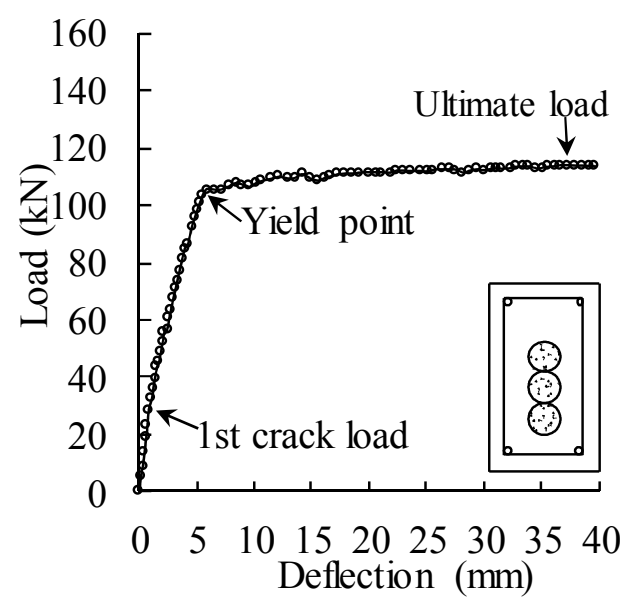

(h) Specimen $\mathrm{P} 8 / \mathrm{N}$

Fig. 4: Load-deflection response of lightweight beam (cont)

Note: The deflection of the curves represent the mid-span deflection of beam. 


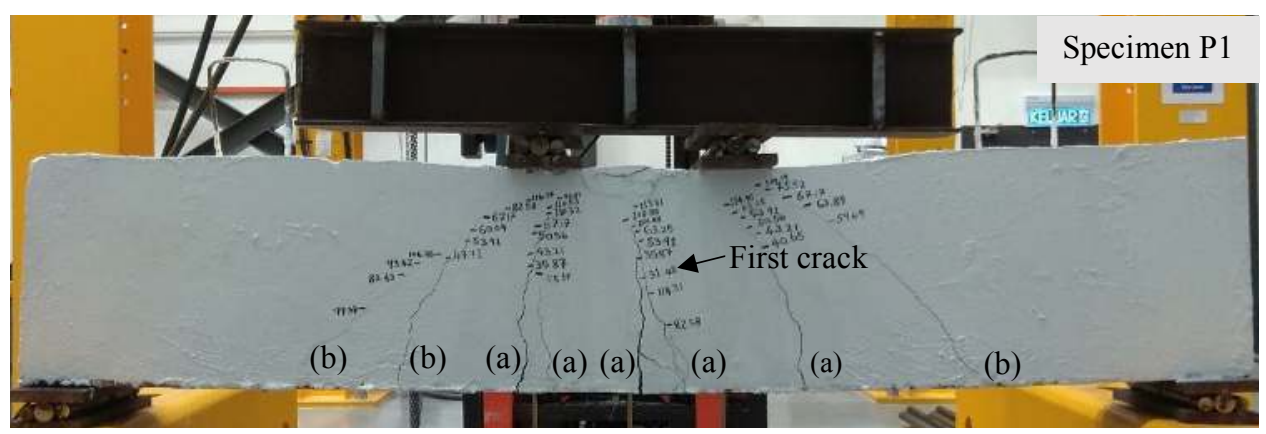

Note: (a) Flexural failure, (b) Diagonal tension

Fig. 5: Failure mode of solid beam

Failure Mode:

The failure mode of the beams was identified from the crack patterns through visual observation and based on the characteristics outlined in Table 5.

Visually, most of the cracks were found to be flexural, followed by diagonal tension, and shear compression (Table 6). In general, there was about (a) 4 to 5 flexural cracks, (b) 2 to 3 diagonal tension cracks, and (c) 0 to 1 shear compression crack. In term of crack width, the flexural crack was always more critical than any other cracks. This indicates that the specimens failed under flexural mode.

TABLE 5. CRITERIA OF FAILURE MODE

\begin{tabular}{l|l|l|l}
\hline Type of crack & Flexural & Diagonal tension & Shear compression \\
\hline Cracking region & $\begin{array}{l}\text { At bottom near the mid- } \\
\text { span, propagating upwards } \\
\text { a }\end{array}$ & $\begin{array}{l}\text { At 1.5d to 2.0d distance } \\
\text { from the support }{ }^{\mathrm{a}}\end{array}$ & $\begin{array}{l}\text { At the support, crush } \\
\text { toward compression zone } \\
\text { a }\end{array}$ \\
\hline Cracking angle $^{\mathrm{d}}$ & $60^{\circ}$ to $90^{\circ}$ & $30^{\circ}$ to $60^{\circ} \mathrm{b}$ & About $45^{\circ}{ }^{\mathrm{c}}$ \\
\hline Crack width $^{\mathrm{e}}$ & $W_{f}>W_{s}$ & $W_{f} \approx W_{s}$ & $W_{f}<W_{s}$ \\
\hline
\end{tabular}

Note: reference: ${ }^{\mathrm{a}}$ Nor and Roslli [10], ${ }^{\mathrm{b}}$ Kum [11], ${ }^{\mathrm{c}}$ Moayyad and Naiem [12]

${ }^{\mathrm{d}}$ Cracking angle from soffit

${ }^{\mathrm{e}} W_{f}=$ crack width of flexural crack, $W_{s}=$ crack width of shear crack

TABLE 6. FAILURE MODE OF SPECIMENS

\begin{tabular}{c|ccc|c|c|c|c}
\hline \multirow{2}{*}{ Specimens } & \multicolumn{3}{|c|}{ Number of crack } & \multicolumn{3}{c|}{ Crack width } & \multirow{2}{*}{ Failure } \\
\cline { 2 - 6 } & $\begin{array}{c}\text { Flexural } \\
\text { failure }\end{array}$ & $\begin{array}{c}\text { Diagonal } \\
\text { tension }\end{array}$ & $\begin{array}{c}\text { Shear } \\
\text { compression }\end{array}$ & $W_{f}>W_{s}$ & $W_{f} \approx W_{s}$ & $W_{f}<W_{s}$ & \\
\hline $\mathrm{P} 1$ & 5 & 3 & - & $\sqrt{ }$ & $\mathrm{X}$ & $\mathrm{X}$ & Flexural \\
$\mathrm{P} 1 / \mathrm{C}$ & 4 & 3 & - & $\sqrt{ }$ & $\mathrm{X}$ & $\mathrm{X}$ & Flexural \\
$\mathrm{P} 2 / \mathrm{N}$ & 4 & 3 & 1 & $\sqrt{ }$ & $\mathrm{X}$ & $\mathrm{X}$ & Flexural \\
$\mathrm{P} 3 / \mathrm{T}$ & 4 & 3 & - & $\sqrt{ }$ & $\mathrm{X}$ & $\mathrm{X}$ & Flexural \\
$\mathrm{P} 4 / \mathrm{CN}$ & 5 & 2 & - & $\sqrt{ }$ & $\mathrm{X}$ & $\mathrm{X}$ & Flexural \\
$\mathrm{P} 5 / \mathrm{NT}$ & 4 & 3 & - & $\sqrt{ }$ & $\mathrm{X}$ & $\mathrm{X}$ & Flexural \\
$\mathrm{P} 6 / \mathrm{T}$ & 5 & 2 & - & $\sqrt{ }$ & $\mathrm{X}$ & $\mathrm{X}$ & Flexural \\
$\mathrm{P} 7 / \mathrm{CNT}$ & 5 & 2 & - & $\sqrt{ }$ & $\mathrm{X}$ & $\mathrm{X}$ & Flexural \\
$\mathrm{P} 8 / \mathrm{NT}$ & 4 & 3 & - & $\sqrt{ }$ & $\mathrm{X}$ & $\mathrm{X}$ & Flexural \\
\hline
\end{tabular}

Table 7 outlines the experiment results of the lightweight beam. In general, the lightweight beams gave a comparable ultimate load capacity as a solid beam. The ultimate load of the beams fell within a range of $-5 \%$ to $+20 \%$ of the solid beam (P1).

The first crack load of the lightweight beam generally increased as the polystyrene was placed further away from the soffit, as observed from specimens P4/CN, P5/NT and P6/T. The first crack load increased $17.3 \%$ as the polystyrene moved from the tension region $(\mathrm{P} 6 / \mathrm{T})$ to the compression region $(\mathrm{P} 4 / \mathrm{CN})$. For a larger concrete volume near the soffit to share the tensile stress with the tension reinforcement bars, the development of the first crack delayed (Fig. $6)$. 


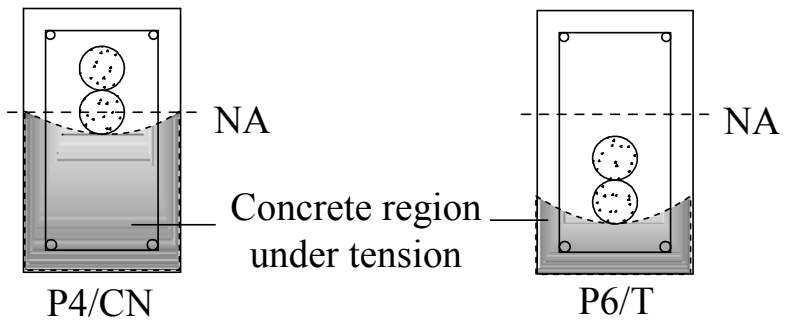

Fig. 6: Concrete region undertaking tensile stress prior to cracking

The yield strength and the ultimate load increased as the centroid of polystyrene from soffit $\left(a_{c}\right)$ decreased. It was observed through a comparison between specimens $\mathrm{P} 1 / \mathrm{C}, \mathrm{P} 2 / \mathrm{N}$ and $\mathrm{P} 3 / \mathrm{T}$. When the centroid of polystyrene from soffit decreased from $232 \mathrm{~mm}$ to $132 \mathrm{~mm}$, the ultimate load increased by $16.3 \%$ (Table 6). Such beneficial effects amplified as the polystyrene was positioned in the lower region of the beam. The concrete at the tension region contributed negligible flexural strength of the beam [13], particularly after the beam cracked. Thus, it could be removed without significantly affect the beam strength.

On the other hand, the ultimate deflection and ductility increased as the percentage of polystyrene increased. Regardless of the replacement region, when the polystyrene in the beam increased by from $2.8 \%$ to $8.4 \%$, (a) the average deflection of the lightweight beams increased from $14.44 \mathrm{~mm}$ to $34.62 \mathrm{~mm}$, and (b) the average ductility ratio increased from 2.38 to 5.93. As the percentage of polystyrene increased, the cross-sectional area of the lightweight beam decreased, the second moment of inertia of the beam section decreased, and thus, larger deflection was developed (Fig. 7).

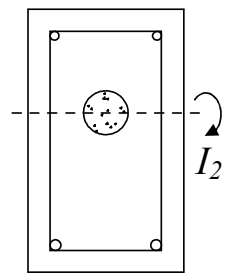

$\mathrm{P} 2 / \mathrm{N}$

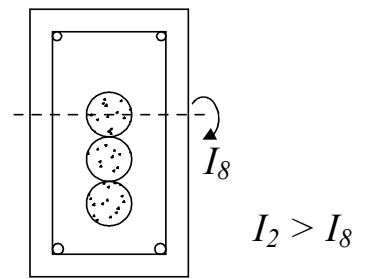

$\mathrm{P} 8 / \mathrm{NT}$

Fig. 7: Second moment of inertia of beam cross-section

TABLE 7. EXPERIMENTAL RESULTS OF THE SPECIMENS

\begin{tabular}{|c|c|c|c|c|c|c|c|}
\hline \multirow[t]{2}{*}{ Specimens } & \multicolumn{2}{|c|}{ Elastic State } & \multicolumn{2}{|c|}{ Yield State } & \multicolumn{2}{|c|}{ Ultimate State } & \multirow{2}{*}{$\begin{array}{c}\text { Ductility, } \\
\Delta=\frac{s u}{s y}\end{array}$} \\
\hline & $\begin{array}{c}\text { First Crack } \\
\text { Load, } \mathrm{P}_{\mathrm{i}} \\
(\mathrm{kN})\end{array}$ & $\begin{array}{c}\text { Stiffness, } \\
E_{o_{-3}} \boldsymbol{F u} \\
(\mathrm{kN} / \mathrm{mm})\end{array}$ & $\begin{array}{c}\text { Yield } \\
\text { Strength, } \\
\mathrm{P}_{\mathrm{y}}(\mathrm{kN})\end{array}$ & $\begin{array}{c}\text { Yield } \\
\text { Deflection } \\
\delta_{\mathrm{y}}(\mathrm{mm})\end{array}$ & $\begin{array}{c}\text { Ultimate } \\
\text { Load, } \mathrm{P}_{\mathrm{u}} \\
(\mathrm{kN})\end{array}$ & $\begin{array}{c}\text { Ultimate } \\
\text { Deflection, } \\
\delta_{\mathrm{u}}(\mathrm{mm})\end{array}$ & \\
\hline $\mathrm{P} 1$ & 31.02 & 18.84 & 108.75 & 6.69 & 118.45 & 30.02 & 4.49 \\
\hline $\mathrm{P} 1 / \mathrm{C}$ & 36.65 & 20.87 & 110.32 & 6.02 & 119.37 & 14.35 & 2.38 \\
\hline $\mathrm{P} 2 / \mathrm{N}$ & 31.38 & 20.42 & 116.52 & 6.61 & 126.01 & 14.27 & 2.16 \\
\hline $\mathrm{P} 3 / \mathrm{T}$ & 35.73 & 24.43 & 126.22 & 5.64 & 142.69 & 14.71 & 2.61 \\
\hline $\mathrm{P} 4 / \mathrm{CN}$ & 35.80 & 19.09 & 104.75 & 6.22 & 118.52 & 11.80 & 2.46 \\
\hline $\mathrm{P} 5 / \mathrm{NT}$ & 32.52 & 24.00 & 107.26 & 6.05 & 119.48 & 20.99 & 3.47 \\
\hline $\mathrm{P} 6 / \mathrm{T}$ & 30.45 & 18.85 & 103.18 & 6.85 & 121.94 & 22.04 & 3.28 \\
\hline $\mathrm{P} 7 / \mathrm{CNT}$ & 33.30 & 18.82 & 100.26 & 5.81 & 111.96 & 32.50 & 5.59 \\
\hline P8/NT & 32.73 & 21.34 & 105.56 & 5.86 & 113.95 & 36.73 & 6.27 \\
\hline
\end{tabular}

\section{Effective Strength to Weight Ratio:}

The lightweight beams were evaluated for effectiveness based on the effective strength-to-weight ratio $(s-w$ ratio) using Equation 1. $W$ and $S$ in Equations 2 and 3 represent the reduction of the weight and the strength of the lightweight beam, respectively, with respect to the solid beam (Specimen P1). An effective lightweight beam would have a higher reduction of the weight than the strength. For that, the $s$ - $w$ ratio is preferably greater than 1 [4]. 


$$
\begin{aligned}
& s-w \text { ratio }=\frac{100-s}{100-W} \\
& \text { Where } W=\frac{w_{S}-w_{L}}{w_{s}} \times 100 \% \\
& S=\frac{s_{s}-s_{L}}{s} \times 100 \% \\
& W_{S}=\text { weight of solid beam } \\
& W_{L}=\text { weight of lightweight beam } \\
& S_{S}=\text { ultimate strength of solid beam } \\
& S_{L}=\text { ultimate strength of lightweight beam }
\end{aligned}
$$

From Table 8, the effectiveness $s-w$ ratio of lightweight beams met the requirement of greater than 1 . The lightweight beams may not necessarily be stronger than the solid beam, particularly for specimens P7/CNT and P8/NT. For a high volume of concrete replacement, the reduction of weight always exceeded the reduction in strength, the lightweight beams were more effective than the solid beam in terms of the strength per unit weight of concrete.

For the industry application, the percentage of concrete being replaced should be significant so that the initiative of reducing the beam's weight is meaningful. For that, specimens P7/CNT and P8/NT with $8.4 \%$ concrete replacement were considered acceptable.

TABLE 8. EFFECTIVE STRENGTH TO WEIGHT RATIO OF PRELIMINARY BEAM

\begin{tabular}{ccccc}
\hline Specimens & $\begin{array}{c}\text { Reduction of } \\
\text { Strength, } S(\%)^{\text {a }}\end{array}$ & $\begin{array}{c}\text { Reduction of } \\
\text { Weight, } W(\%)\end{array}$ & $\begin{array}{c}\text { Effective Strength to } \\
\text { Weight Ratio, (s-w ratio) }\end{array}$ & $\begin{array}{c}\text { Remarks } \\
(\mathrm{A} / \mathrm{NA})\end{array}$ \\
\hline Equation & $(2.2)$ & $(2.1)$ & $(2.3)$ & - \\
\hline P1 & - & - & 1.00 & $\mathrm{~A}$ \\
$\mathrm{P} 1 / \mathrm{C}$ & -0.8 & 2.8 & 1.04 & $\mathrm{~A}$ \\
$\mathrm{P} 2 / \mathrm{N}$ & -6.4 & 2.8 & 1.09 & $\mathrm{~A}$ \\
$\mathrm{P} 3 / \mathrm{T}$ & -20.5 & 2.8 & 1.24 & $\mathrm{~A}$ \\
$\mathrm{P} 4 / \mathrm{CN}$ & -0.1 & 5.6 & 1.06 & $\mathrm{~A}$ \\
$\mathrm{P} 5 / \mathrm{NT}$ & -0.9 & 5.6 & 1.07 & $\mathrm{~A}$ \\
P6/T & -2.9 & 5.6 & 1.09 & $\mathrm{~A}$ \\
$\mathrm{P} 7 / \mathrm{CNT}$ & 5.5 & 8.4 & 1.03 & $\mathrm{~A}$ \\
P8/NT & 3.8 & 8.4 & 1.05 & $\mathrm{~A}$ \\
\hline
\end{tabular}

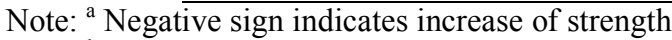

${ }^{\mathrm{b}} \mathrm{A}=$ Adequate $(\mathrm{s}-\mathrm{w}$ ratio $\geq 1.0), \mathrm{NA}=$ Non-adequate $(\mathrm{s}-\mathrm{w}$ ratio $<1.0)$

\section{CONCLUSIONS}

This study aimed to investigate the behaviour of the lightweight beams and determines the best position of polystyrene blocks in beams. The specimen was evaluated in terms of (a) the load-deflection responses, (b) the failure modes, (c) the mechanical properties, and (d) the s-w ratio.

From the results, it is found that:

(a) The occurrence of the first crack delayed as the centroid of the polystyrene blocks from the soffit increased, thus higher first crack load can be achieved.

(b) The yield strength and ultimate load of lightweight beams increased as the centroid of the polystyrene blocks from the soffit decreased.

(c) The ultimate deflection and ductility of lightweight beams increased as the percentage of concrete replacement increased.

(d) The effective strength-to-weight ratios for all the beams were greater than 1.0, which was considered effective. Less concrete was required to achieve comparable strength as a solid beam.

For that, it is possible to reduce the weight of the lightweight beam up to $8.4 \%$ without compromising the effectiveness of the beam. This can be achieved by embed polystyrene block in the neutral and tension region of RC beam.

\section{ACKNOWLEDGMENT}

This work was supported by the Research Grants of University College of Technology Sarawak, UCTS/RESEARCH/1/2018/09. 
Y. T. Lim, J. H. Ling, J. W. Lau, T. T. L. Danson

\section{SYMBOLS}

\begin{tabular}{|c|c|}
\hline$d$ & Effective depth of beam, $\mathrm{mm}$ \\
\hline$d_{i}$ & Centroid of polystyrene from soffit, $\mathrm{mm}$ \\
\hline$d_{g}$ & Diameter of polystyrene, $\mathrm{mm}$ \\
\hline$E_{0,75 u}$ & Secant Stiffness before the yield state of beam, $\mathrm{kN} / \mathrm{mm}$ \\
\hline Sy & Specified yield strength of reinforcement bars, N/mm ${ }^{2}$ \\
\hline$l_{\text {eff }}$ & Effective length of beam, mm \\
\hline$l_{\mathrm{p}}$ & Length of polystyrene, $\mathrm{mm}$ \\
\hline$\dot{p}$ & Load capacity of beam, $\mathrm{kN}$ \\
\hline$P_{i}$ & First crack load of beam, $\mathrm{kN}$ \\
\hline$P_{u}$ & Ultimate load of beam, $\mathrm{kN}$ \\
\hline$P_{y}$ & Yield strength of beam, $\mathrm{kN}$ \\
\hline$s-w$ ratio & Effective strength to weight ratio \\
\hline 5 & Reduction of strength, $\%$ \\
\hline$s_{2}$ & Strength of the lightweight beam, $\mathrm{kN}$ \\
\hline$s_{S}$ & Strength of the solid beam, $\mathrm{kN}$ \\
\hline$W$ & Reduction of weight, $\%$ \\
\hline$W_{f}$ & Width of the flexural crack, mm \\
\hline$W_{z}$ & Weight of lightweight beam, $\mathrm{kg}$ \\
\hline$W_{s}$ & Weight of solid beam, $\mathrm{kg}$ \\
\hline$W_{l}$ & Width of the shear crack, mm \\
\hline$V^{*}$ & Percentage of Concrete Replaced, \% \\
\hline$x_{1}$ & Distance between two loading points, $\mathrm{mm}$ \\
\hline$\delta$ & Deflection of beam, mm \\
\hline$\delta_{u}$ & Ultimate deflection of beam, $\mathrm{mm}$ \\
\hline$\delta_{y}$ & Yield deflection of beam, $\mathrm{mm}$ \\
\hline$\Delta$ & Ductility of beam \\
\hline
\end{tabular}

\section{REFERENCES}

[1] V. Anju, and B.M. Joseph, "Experimental and numerical studies on reinforced concrete hollowcore sandwich beams', International Journal of Innovative Research in Science, Engineering and Technology, vol. 5, pp. 14730 14737, 2016.

[2] A.E. Ajeel, T.A. Qaseem, and S.R. Rasheed, "Structural behavior of voided reinforced concrete beams under combined moments", Civil and Environmental Research, vol. 10, pp. 17 - 24, 2018.

[3] J. Joy, and R. Rajeev, "Effect of reinforced concrete beam with hollow neutral axis", International Journal for Scientific Research and Development, vol. 2, pp. 341 - 348, 2014.

[4] Y.T. Lim, and J.H. Ling, "Incorporating lightweight materials in reinforced concrete beams and slabs - a review", Borneo Journal of Sciences and Technology, vol 1, pp. 16-26, 2019.

[5] J.H.A. Ahmad, and N.G.M. Hadi, "Structural behavior of reinforced concrete hollow beams under partial uniformly distributed load", International Journal of Engineering, vol 20, pp. 130 - 145, 2014.

[6] S. Manikandan, S. Dharnar, and S. Robertravi, "Experimental study on flexural behaviour of reinforced concrete hollow core sandwich beams", International Journal of Advance Research in Science and Engineering, vol 4, pp. $937-946,2015$.

[7] P. Sivaneshan, and S. Harishankar, "Experimental study on voided reinforced concrete beams with polythene balls", Conference on Earth and Environmental Science, Cyprus, Famagusta, pp. 1 - 8, 2017.

[8] A. Noushini, B. Samali, and A. Vessalas, "Performance of concrete beam element reinforced with polyvinyl alcohol (PVA) mirco fibres, Concrete in Australia, vol. 40, pp. 22 - 27, 2014.

[9] R. Park, "Ductility evaluation from laboratory and analytical testing", The 9th World Conference on Earthquake Engineering, Tokyo-Kyoto, Japan, pp. 605 - 616, 1988.

[10] F.Z. Nor, and N.M. Roslli, "The effects of inclined shear reinforcement in reinforced concrete beam, pp. 138 - 149 , 2014. 
[11] Y.J. Kum, "Cracking mode and shear strength of lightweight concrete beams", Singapore: National University of Singapore, 2011.

[12] M.A. Moayyad, and M.A. Naiem, "Shear reinforcements in the reinforced concrete beams", American Journal of Engineering Research (AJER), vol. 2, pp. 191 - 199, 2013.

[13] S.Y. Mohamad, and A. Ramli, "Reinforced Concrete Design to Eurocode 2", Malaysia: University Teknologi Malaysia, 2012. 